\title{
Collagen peptides from soft-shelled turtle induce calpain-1 expression and regulate inflammatory cytokine expression in HaCaT human skin keratinocytes
}

\author{
TETSUSHI YAMAMOTO, SAORI NAKANISHI, KUNIKO MITAMURA and ATSUSHI TAGA \\ Pathological and Biomolecule Analyses Laboratory, Faculty of Pharmacy, \\ Kindai University, Higashi-Osaka, Osaka 577-8502, Japan
}

Received December 26, 2017; Accepted May 3, 2018

DOI: $10.3892 /$ ijmm.2018.3659

\begin{abstract}
Collagen peptides (CPs), derived by hydrolyzing collagen with chemicals or enzymes, are often used as functional materials, due to their various bioactivities and high bioavailability. A previous study by our group reported that collagen from soft-shelled turtle, Pelodiscus sinensis, induces keratinocytes to undergo epithelial-mesenchymal transition and facilitates wound healing. Therefore, CPs derived from soft-shelled turtle collagen may have useful effects on the skin. In the present study, the functional effects of CPs on human skin were examined by analyzing CP-treated human keratinocytes with a shotgun liquid chromatography/mass spectrometry-based global proteomic approach. A semi-quantitative method based on spectral counting was applied and 211 proteins that exhibited $>2$-fold changes in expression after CP treatment were successfully identified. Based on a Gene Ontology analysis, the functions of these proteins were indicated to be closely linked with protein processing. In addition, CP treatment significantly increased the expression of calpain-1, a calcium-dependent intracellular cysteine protease. Furthermore, CP-treated keratinocytes exhibited elevated interleukin (IL)-1 $\alpha$ and IL-8 expression and reduced IL-6 expression. CPs also induced the expression of proteins implicated in cell-cell adhesion and the skin barrier. Therefore, CPs from soft-shelled turtle may provide significant
\end{abstract}

Correspondence to: Dr Atsushi Taga, Pathological and Biomolecule Analyses Laboratory, Faculty of Pharmacy, Kindai University, 3-4-1 Kowakae, Higashi-Osaka, Osaka 577-8502, Japan

E-mail: punk@phar.kindai.ac.jp

Abbreviations: MALDI-TOF/MS, matrix-assisted laser desorptiontime of flight/mass spectrometry; LC-MS/MS, liquid chromatography tandem mass spectrometry; NSAF, normalized spectral abundance factor; RT-PCR, reverse transcription-polymerase chain reaction; IL, interleukin; TNF, tumor necrosis factor

Key words: collagen peptide, proteomics, soft-shelled turtle, calpain-1, cytokine benefits for maintaining the biological environment of the skin, and may be useful as components of pharmaceuticals and medical products.

\section{Introduction}

Collagen is a ubiquitous structural protein. There are more than 20 different types of collagen, with specific functions in each tissue $(1,2)$. These proteins have important roles in the maintenance of the extracellular matrix environment (3-7). Certain studies have demonstrated that collagen regulates cell proliferation or apoptosis $(8,9)$. In this decade, collagens of marine origin (e.g., fish, sponges and mollusks) have been considered a useful resource due to their high availability (10-17). These collagens have been widely used as functional foods or dietary supplements. Collagen has also been used for skin substitutes and drug delivery vehicles (18-23).

Recently, collagen peptides (CPs), derived from chemical and enzymatic collagen hydrolysis $(24,25)$, have been increasingly used as functional materials, due to their various bioactivities and high bioavailability $(26,27)$. Several studies have demonstrated the beneficial effects of CPs. For instance, CPs derived from fish skin were demonstrated to have several protective effects on skin photo-aging and wound healing, as they improved moisture retention and repaired endogenous collagen and elastin protein fibers (28-32). Therefore, CPs are considered a useful material for the development of cosmetics, pharmaceuticals and medical products.

Previous studies by our group reported that tissue from soft-shelled turtle, Pelodiscus sinensis, may be a useful alternative source of collagen (33). Due its ability to induce keratinocytes to enter the epithelial-mesenchymal transition (EMT), which facilitates wound healing, this collagen may be a useful component of pharmaceuticals and medical products (34). Furthermore, CPs from soft-shelled turtle may have beneficial effects on skin. However, due to differences in habitat environments, collagen from soft-shelled turtle may differ greatly from collagen from mammalian or marine sources, in terms of physicochemical properties, amino acid composition and physiological functions. Therefore, further research is required prior to the use of CPs derived from soft-shelled turtle tissue in commercial products. 
In the present study, a shotgun liquid chromatography/mass spectrometry (LC/MS)-based global proteomic analysis of human keratinocytes treated with CPs was performed to examine the functional effects of CPs on human skin. A total of 211 differentially expressed proteins was identified in keratinocytes treated with CPs compared with untreated keratinocytes. It was investigated whether any of these proteins may be involved in the induction of inflammatory factors in human skin.

\section{Materials and methods}

Chemicals and reagents. The highest-grade chemicals and reagents available were purchased from Wako Pure Chemical Industries (Osaka, Japan). Emperor tissue, a soft tissue in the region around the shell of soft-shelled turtles ( $P$. sinensis), was provided by Shin-uoei, Inc. (Osaka, Japan).

Collagen extraction. Collagen extraction was performed as described in a previous study (33). In brief, emperor tissue was treated with $0.1 \mathrm{M}$ formic acid at a ratio of $1: 10(\mathrm{w} / \mathrm{v})$ for $24 \mathrm{~h}$ for demineralization. The sample was then treated with $0.1 \mathrm{M} \mathrm{NaOH}$ at a ratio of 1:10 (w/v) for 3 days to remove non-collagenous proteins, including endogenous proteases. The $\mathrm{NaOH}$ solution was changed every day. Finally, the sample was incubated with $0.03 \mathrm{M}$ citric acid for $24 \mathrm{~h}$. After the incubation, the solution was centrifuged at $6,500 \mathrm{x} g$ for $20 \mathrm{~min}$ at $4^{\circ} \mathrm{C}$, and the supernatant was collected. This collagen solution was used in the subsequent experiments.

Tryptic digestion of collagen. The extracted collagen solution was subjected to proteolytic activation with bovine pancreatic trypsin (Sigma-Aldrich; Merck KGaA, Darmstadt, Germany) in $100 \mathrm{mM}$ ammonium bicarbonate buffer ( $\mathrm{pH} \mathrm{8.0)}$. The collagen was incubated with trypsin at a trypsin/collagen ratio of 1:100 (w:w) at $37^{\circ} \mathrm{C}$. At each indicated time-point, reaction solutions were quickly removed and heated to $100^{\circ} \mathrm{C}$ to terminate trypsin digestion.

Tricine-SDS-PAGE. The molecular weights of the tryptic digestion products were determined with tricine-SDS-PAGE, as described previously (35). For comparison, molecular weight markers ranging from 3.5 to $42 \mathrm{kDa}$ (Wako Pure Chemical Industries) were used. The electrophoresed gel was stained with Coomassie brilliant blue at room temperature for $1 \mathrm{~h}$.

Matrix-assisted laser desorption-time of flight/mass spectrometry (MALDI-TOF/MS). CPs were applied onto the MALDI target plate (Shimadzu, Kyoto, Japan) with $10 \mathrm{mg} / \mathrm{ml}$ of $\alpha$-cyano-4-hydroxy cinnamic acid (Sigma-Aldrich; Merck $\mathrm{KGaA}$ ) in $50 \%$ acetonitrile and $0.05 \%$ trifluoroacetic acid. The mass spectra of the CPs were determined with an AXIMA Confidence (Shimadzu) in reflector mode. Prior to acquiring the peptide mass spectrum of the sample, the system was calibrated with a ProteoMass Peptide \& Protein MALDI-MS Calibration Kit (cat. no. MSCAL1-1KT; Bradykinin fragment 1-7, 757.3997; $\mathrm{P}_{14} \mathrm{R}, 1,533.8582$; insulin oxidized B-chain, 3,494.6513; Sigma-Aldrich; Merck KGaA).

Cell culture. HaCaT immortalized human keratinocytes were purchased from CLS Cell Lines Service GmbH (Eppelheim,
Germany). The cells were cultured in RPMI-1640 medium supplemented with $10 \%$ fetal bovine serum (Gibco; Thermo Fisher Scientific, Inc., Waltham, MA, USA) in an atmosphere containing $5 \% \mathrm{CO}_{2}$ at $37^{\circ} \mathrm{C}$.

Cell growth assay. Cells were plated at a density of $5 \times 10^{3}$ cells/well in a 96-well plate and grown in culture medium. The medium was changed the next day, and different concentrations of CPs were added. After 72-h treatments, the cells were incubated with the WST- 8 cell counting reagent (Wako Pure Chemical Industries), and the optical density of the culture solution was measured at $450 \mathrm{~nm}$ with an ELISA plate reader.

Protein preparation. $\mathrm{HaCaT}$ cells were plated in a $60-\mathrm{mm}$ dish at a density of $2 \times 10^{5}$ cells per dish and grown in culture medium. The medium was changed the next day and CPs were added. After 72-h treatments, the cells were solubilized in urea lysis buffer (7 M urea, $2 \mathrm{M}$ thiourea, 5\% CHAPS, $1 \%$ Triton X-100). The protein concentration was measured with the Bio-Rad Protein Assay (cat. no. 5000006JA; Bio-Rad Laboratories, Hercules, CA, USA).

In-solution trypsin digestion. The gel-free digestion method was applied as described previously (36). In brief, $10 \mu \mathrm{g}$ protein extract from each sample was chemically reduced by adding $45 \mathrm{mM}$ dithiothreitol and $20 \mathrm{mM}$ tris(2-carboxyethyl)phosphine. Subsequently, the protein was alkylated with $100 \mathrm{mM}$ iodoacetamide. After the alkylation, the samples were digested with mass spectrometry grade trypsin gold (Promega Corp., Madison, WI, USA) at $37^{\circ} \mathrm{C}$ for $24 \mathrm{~h}$. Next, the digests were purified with PepClean C-18 Spin Columns (Thermo Fisher Scientific, Inc.) according to the manufacturer's protocol.

Liquid chromatography tandem MS (LC-MS/MS) analysis for protein identification. Peptide samples $(\sim 2 \mu \mathrm{g})$ were injected into a peptide L-trap column (Chemicals Evaluation and Research Institute, Tokyo, Japan) with an HTC PAL autosampler (CTC Analytics, Zwingen, Switzerland). The peptides were separated further in a Paradigm MS4 (AMR Inc., Tokyo, Japan) with a reverse-phase C18-column (L-column, 3- $\mu$ m-diameter gel particles and $120 \AA$ pore size, $0.2 \times 150 \mathrm{~mm}$, Chemicals Evaluation and Research Institute). The mobile phase consisted of $0.1 \%$ formic acid in water (solution $\mathrm{A}$ ) and acetonitrile (solution B). The column flow rate was $1 \mu \mathrm{l} / \mathrm{min}$ with a concentration gradient of $5 \%$ B to $40 \%$ B over $120 \mathrm{~min}$. Gradient-eluted peptides were analyzed with an LTQ ion-trap mass spectrometer (Thermo Fisher Scientific, Inc.). The results were acquired in a data-dependent manner, where MS/MS fragmentation was performed on the two most intense peaks of each full MS scan.

All MS/MS spectral data were entered into a search for comparisons against the SwissProt Homo sapiens database with the Mascot tool (version 2.4.01; Matrix Science, London, UK). The search criteria were as follows: Enzyme, trypsin; with the following allowances: Up to two missed cleavage peptides; mass tolerance, $\pm 2.0 \mathrm{kDa} ; \mathrm{MS} / \mathrm{MS}$ tolerance, $\pm 0.8 \mathrm{kDa}$; and cysteine carbamidomethylation and methionine oxidation modifications.

Semiquantitative analysis of identified proteins. The fold-change in expression was calculated as the $\log _{2}$ of the 
ratio of protein abundances (Rsc), evaluated by spectral counting (37). For comparison, the relative amounts of identified proteins were calculated using the normalized spectral abundance factor (NSAF) (38). Differential expression of proteins were considered significant when the Rsc was $>1$ or $<-1$, which corresponded to fold-changes of $>2$ or $<0.5$, respectively.

Bioinformatics. The function of proteins that exhibited a significant change in expression with $\mathrm{CP}$ treatment was investigated. These sequences were processed by examining their functional annotations in the Database for Annotation, Visualization, and Integrated Discovery (DAVID) version 6.8 (http://david.abcc.ncifcrf.gov/home.jsp) (39-41).

Western blot analysis. Total protein $(5 \mu \mathrm{g})$ that had been extracted from CP-treated cells was added to each well of an SDS-PAGE gel and electrophoresis was performed under reducing conditions. The separated proteins were transferred to polyvinylidene fluoride membranes (Merck KGaA) for $30 \mathrm{~min}$ at $15 \mathrm{~V}$. After blocking in TBS-Tween-20 (0.1\%) buffer with $5 \%$ skimmed milk for $2 \mathrm{~h}$ at room temperature, the membranes were incubated with an anti-calpain 1 antibody (1:1,000 dilution; cat. no. 2556; Cell Signaling Technology, Inc., Beverly, MA, USA) at $4^{\circ} \mathrm{C}$ overnight. The membranes were then washed and incubated with horseradish peroxidase-conjugated anti-rabbit immunoglobulin (Ig)G antibody (cat. no. A106PU; American Qualex, San Clemente, CA, USA) at room temperature for $1 \mathrm{~h}$. The blots were washed and visualized with SuperSignal West Dura Extended Duration substrate (Thermo Fisher Scientific, Inc.). The bands were analyzed with the myECL Imager system (version 2.0; Thermo Fisher Scientific, Inc.). Next, the membranes were stripped by Restore Western Blot Stripping buffer (Thermo Fisher Scientific, Inc.), and the same membranes were re-probed with an anti- $\beta$-actin antibody (1:5,000 dilution; cat. no. sc-47778; Santa Cruz Biotechnology, Inc., Dallas, TX, USA) at $4^{\circ} \mathrm{C}$ overnight, which served as the protein loading control. The intensities of calpain- 1 and $\beta$-actin were quantified with myImageAnalysis software (version 2.0; Thermo Fisher Scientific, Inc.). The relative quantities of calpain-1 over $\beta$-actin were used to evaluate calpain-1 expression under different conditions. All western blot analyses were performed as three independent experiments.

Reverse transcription-quantitative polymerase chain reaction $(R T-q P C R)$. Total RNA was extracted from HaCaT cells with the GenElute Mammalian Total RNA Miniprep kit (cat. no. RTN70-1KT; Sigma-Aldrich; Merck KGaA). Complementary (c)DNA was synthesized with the High Capacity cDNA Reverse Transcription kit (cat. no. 4368814; Thermo Fisher Scientific, Inc.) according to the manufacturer's protocols. To measure the expression levels of interleukin (IL)-1 $\alpha$, IL-6, IL-8 and tumor necrosis factor (TNF)- $\alpha$, PCR amplification was performed in the 7500 system (Applied Biosystems; Thermo Fisher Scientific, Inc.). Primers and TaqMan probes for detecting IL-1 $\alpha$ (assay ID, Hs00174092_m1), IL-6 (assay ID, Hs00985639_m1), IL-8 (assay ID, Hs00174103_m1), TNF- $\alpha$ (assay ID,Hs01113624_g1) and 18S ribosomal (r)RNA (assay ID, Hs03928990_g1) were supplied with the TaqMan Gene Expression Assay (Applied
Biosystems; Thermo Fisher Scientific, Inc.). The relative gene expression was calculated via the $\Delta \Delta \mathrm{Cq}$ method (42-46). The $\Delta \Delta \mathrm{Cq}$ method uses the normalized $\Delta \mathrm{Cq}$ value of each sample, which was calculated with $18 \mathrm{~S}$ rRNA as the endogenous control gene. The $\Delta \Delta \mathrm{Cq}$ value is the difference between treated and control samples. Finally, the fold-change was determined as $2^{-\Delta \Delta C q}$. Gene expression was evaluated in triplicate.

Statistical analysis. All data are presented as the mean \pm standard error of the mean. The data were analyzed by one-way analysis of variance followed by Dunnett's test or the unpaired Student's t-test for two groups. $\mathrm{P}<0.05$ was considered to indicate a significant difference. Computations were performed with GraphPad Prism version 5.1 (GraphPad Software Inc., La Jolla, CA, USA).

\section{Results}

Tryptic digestion of collagen from soft-shelled turtle. Collagen extracted from soft-shelled turtle was digested with trypsin to obtain CPs with molecular weights of $<3.5 \mathrm{kDa}$. The collagen digestion was monitored by extracting samples at different time-points. The samples were separated on a $15 \%$ tricine-SDS-PAGE gel (Fig. 1A). After $1 \mathrm{~h}$ of trypsin digestion, bands that corresponded to collagen or CPs at around $42 \mathrm{kDa}$ were observed (Fig. 1A; black square). After $96 \mathrm{~h}$, these bands completely disappeared (Fig. 1A). The molecular weight distribution of the digested CPs was evaluated using MALDI-TOF/MS. The results indicated that the collagen was digested to CPs with a molecular weight of $\angle 4.0 \mathrm{kDa}$, and most CPs had mass-to-charge ( $\mathrm{m} / \mathrm{z}$ ) ratios of 800-2,500 (Fig. 1B).

Cytotoxicity of CPs to HaCaT cells. To examine the possible cytotoxic effects of CPs on HaCaT cells, it was assessed whether the cell growth rate was affected when the cells were grown in culture medium containing CPs at concentrations of $0.1-100 \mu \mathrm{g} / \mathrm{ml}$. The results indicated that CPs did not inhibit the $\mathrm{HaCaT}$ cell growth rate at any of the tested concentrations (Fig. 2). Therefore, the CPs were used at a concentration of $100 \mu \mathrm{g} / \mathrm{ml}$ in the subsequent experiments.

Identification and semi-quantitative comparison of differentially expressed proteins in CP-treated HaCaT cells. Next, the potential effect of CPs on cells in the basal layer of the skin was investigated by treating $\mathrm{HaCaT}$ cells with CPs. To determine the molecular profile of proteins that are regulated by CPs, a shotgun proteomics approach was used. A label-free semi-quantitative method based on spectral counting was utilized to evaluate the proteins expressed in $\mathrm{HaCaT}$ cells. The Rsc values were calculated for proteins that had been identified in CP-treated HaCaT cells and untreated cells. A positive value indicated increased expression by $\mathrm{CP}$-treatment and a negative value indicated reduced expression by CP-treatment (Fig. 3; light grey area). For each protein that had been identified in CP-treated HaCaT cells and untreated cells, the NSAF value was also calculated (Fig. 3; black bars; peptides, grey bar; control). Proteins with a $>1$ and $<-1$ Rsc value were considered candidate CP-regulated proteins.

Based on this semi-quantitative procedure, a total of 211 proteins that were differentially expressed with CP treatment were identified (Table I). The expression of housekeeping 

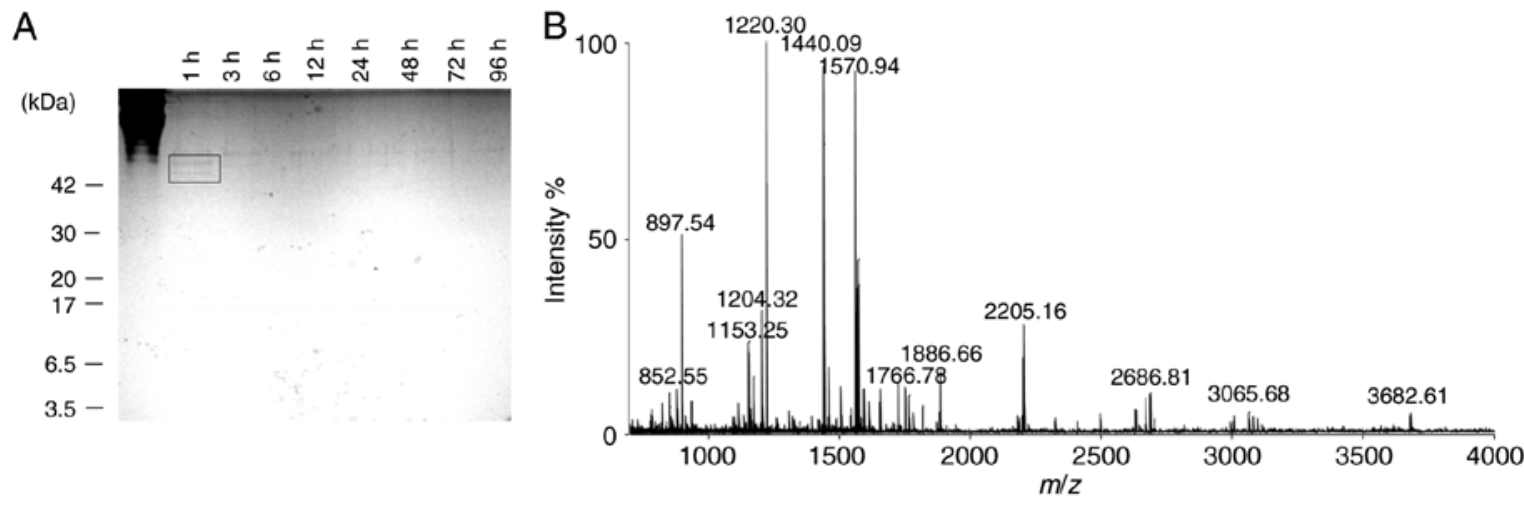

Figure 1. Characterization of collagen peptides obtained by digesting soft-shelled turtle collagen with trypsin. (A) Protein profiles of tryptic digestion products obtained using 15\% tricine-SDS-PAGE. Samples were extracted at the indicated incubation times. Molecular weight markers (kDa) are indicated on the left. (B) Matrix-assisted laser desorption ionization-time of flight/mass spectrometry positive ion mass spectra of digested collagen peptides mixture. The $\mathrm{m} / \mathrm{z}$ values are stated above the corresponding peaks. $\mathrm{m} / \mathrm{z}$, mass to charge ratio.

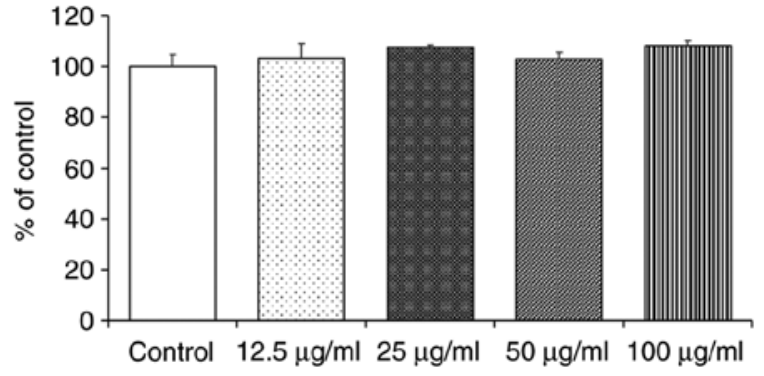

Figure 2. Cytotoxic effect of collagen peptides on HaCaT cells. Different concentrations of collagen peptides were added to $\mathrm{HaCaT}$ cells. None of these concentrations affected the cell proliferation at $72 \mathrm{~h}$.

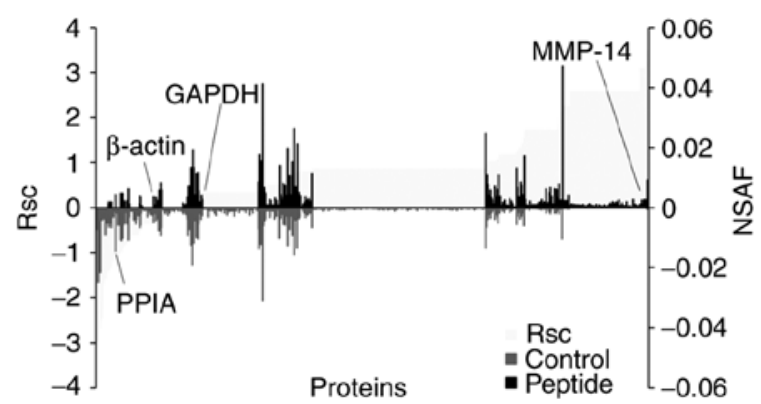

Figure 3. Semi-quantitative comparison of proteins in $\mathrm{HaCaT}$ cells that were differentially expressed with collagen peptide treatments. The Rsc and the NSAF values were calculated for identified proteins to compare protein expression levels between untreated (control) and collagen-peptide-treated $\mathrm{HaCaT}$ cells. Cell proteins are placed along the x-axis, ordered according to the Rsc value, increasing from left to right (light grey area). NSAF values from control cells are displayed below the axis (grey bars), and values from peptide-treated cells are placed above the axis (black bars). Proteins highly expressed in control and peptide-treated cells are near the left and right sides, respectively, of the x-axis. Housekeeping proteins are located near the center of the $\mathrm{x}$-axis. Rsc, $\log _{2}$ of the ratio of protein abundance; NSAF, normalized spectral abundance factor; PPIA, peptidylprolyl isomerase A; MMP, matrix metalloproteinase.

proteins, including $\beta$-actin and GAPDH, was not altered by CP treatment.

Functional annotation of proteins regulated by CPs. A gene ontology (GO) analysis of the candidate CP-regulated proteins was then performed. GO terms associated with 'pathway' (Fig. 4A) and 'molecular function' (Fig. 4B) were searched for in DAVID. The search focused on proteins classified as 'protein processing in endoplasmic reticulum' (Table II).

Effect of CP on calpain-1 expression in HaCaT cells. To confirm that $\mathrm{CP}$ treatment altered caipain-1 expression, caipain-1 protein levels were examined in $\mathrm{CP}$-treated $\mathrm{HaCaT}$ cells. It was identified that caipain-1 expression was significantly increased with $\mathrm{CP}$ treatment compared with that in control cells (Fig. 5).

Effect of CP treatment on the expression of inflammatory factors in $\mathrm{HaCaT}$ cells. To investigate whether the CP-induced increase in calpain-1 expression was associated with the expression of inflammatory cytokines in $\mathrm{HaCaT}$ cells, expression levels of IL-1 $\alpha$, IL-6, IL-8 and TNF- $\alpha$ were examined (Fig. 6). Although $\mathrm{CP}$-treated $\mathrm{HaCaT}$ cells tended to exhibit increases in IL-1 $\alpha$ expression (Fig. 6A), the change was not significant $(\mathrm{P}=0.0781)$. However, IL-6 expression was significantly decreased in $\mathrm{HaCaT}$ cells treated with $\mathrm{CP}$, and by contrast, IL-8 expression was significantly increased with CP treatment (Fig. 6B and C). Finally, CPs had no effect on TNF- $\alpha$ expression (Fig. 6D).

\section{Discussion}

In the present study, a gel-free LC-MS-based proteomics approach was used to examine the functional effects of soft-shelled turtle CPs on human skin cells. A total of 211 proteins that exhibited $>2$-fold changes in expression after CP treatment were successfully identified in HaCaT cells, based on a semi-quantitative method of spectral counting. To examine the roles of these identified proteins, a GO analysis was performed. The study focused on the functions of proteins classified as 'protein processing in endoplasmic reticulum', as they have important roles in the synthesis of correctly folded proteins and in the degradation of misfolded proteins. The function of calpain-1, which is a member of this pathway, was also examined.

To validate the spectral counting results, a western blot analysis was performed to examine whether calpain-1 
Table I. Proteins differentially expressed ( $\geq 2$-fold) after treatment with collagen peptides.

\begin{tabular}{|c|c|c|c|c|}
\hline ID & $\begin{array}{l}\text { Accession } \\
\text { number }\end{array}$ & Definition & $\begin{array}{l}\text { Number of } \\
\text { amino acids }\end{array}$ & $\begin{array}{c}\text { Fold } \\
\text { change (Rsc) }\end{array}$ \\
\hline TBA1B_HUMAN & P68363 & Tubulin $\alpha-1 \mathrm{~B}$ chain & 451 & -2.937 \\
\hline H2B1L_HUMAN & Q99880 & Histone $\mathrm{H} 2 \mathrm{~B}$ type $1-\mathrm{L}$ & 126 & -2.890 \\
\hline H2B1B_HUMAN & P33778 & Histone $\mathrm{H} 2 \mathrm{~B}$ type $1-\mathrm{B}$ & 126 & -2.683 \\
\hline H2B1K_HUMAN & O60814 & Histone $\mathrm{H} 2 \mathrm{~B}$ type $1-\mathrm{K}$ & 126 & -2.683 \\
\hline K2C75_HUMAN & O95678 & Keratin, type II cytoskeletal 75 & 551 & -2.507 \\
\hline K2C4_HUMAN & P19013 & Keratin, type II cytoskeletal 4 & 534 & -2.443 \\
\hline K2C79_HUMAN & Q5XKE5 & Keratin, type II cytoskeletal 79 & 535 & -2.073 \\
\hline ATPA_HUMAN & P25705 & ATP synthase subunit $\alpha$, mitochondrial & 553 & -2.073 \\
\hline HS902_HUMAN & Q14568 & Putative heat shock protein HSP $90-\alpha$ A2 & 343 & -1.691 \\
\hline HSP7C_HUMAN & P11142 & Heat shock cognate $71 \mathrm{kDa}$ protein & 646 & -1.577 \\
\hline H2A1B_HUMAN & P04908 & Histone $\mathrm{H} 2 \mathrm{~A}$ type 1-B/E & 130 & -1.577 \\
\hline K2C6C_HUMAN & P48668 & Keratin, type II cytoskeletal 6C & 564 & -1.409 \\
\hline K2C5_HUMAN & P13647 & Keratin, type II cytoskeletal 5 & 590 & -1.384 \\
\hline TBA3C_HUMAN & Q13748 & Tubulin $\alpha-3 C / D$ chain & 450 & -1.383 \\
\hline HS90B_HUMAN & P08238 & Heat shock protein HSP $90-\beta$ & 724 & -1.343 \\
\hline K1C19_HUMAN & P08727 & Keratin, type I cytoskeletal 19 & 400 & -1.245 \\
\hline TBA3E_HUMAN & Q6PEY2 & Tubulin $\alpha-3 \mathrm{E}$ chain & 450 & -1.171 \\
\hline TPIS_HUMAN & P60174 & Triosephosphate isomerase & 286 & -1.171 \\
\hline LMNA_HUMAN & P02545 & Prelamin-A/C & 664 & -1.171 \\
\hline K2C3_HUMAN & P12035 & Keratin, type II cytoskeletal 3 & 628 & -1.171 \\
\hline PPIA_HUMAN & P62937 & Peptidyl-prolyl cis-trans isomerase A & 165 & -1.125 \\
\hline K2C73_HUMAN & Q86Y46 & Keratin, type II cytoskeletal 73 & 540 & -1.005 \\
\hline HS904_HUMAN & Q58FG1 & Putative heat shock protein HSP 90- $\alpha$ A4 & 418 & -1.005 \\
\hline RS12_HUMAN & P25398 & 40S ribosomal protein $\mathrm{S} 12$ & 132 & -1.005 \\
\hline H2A1A_HUMAN & Q96QV6 & Histone $\mathrm{H} 2 \mathrm{~A}$ type $1-\mathrm{A}$ & 131 & -1.005 \\
\hline FAS_HUMAN & P49327 & Fatty acid synthase & 2,511 & -1.005 \\
\hline K1C18_HUMAN & P05783 & Keratin, type I cytoskeletal 18 & 430 & 1.009 \\
\hline KRT84_HUMAN & Q9NSB2 & Keratin, type II cuticular Hb4 & 600 & 1.029 \\
\hline H2B1A_HUMAN & Q96A08 & Histone H2B type 1-A & 127 & 1.029 \\
\hline PSA2_HUMAN & P25787 & Proteasome subunit $\alpha$ type- 2 & 234 & 1.029 \\
\hline PHB2_HUMAN & Q99623 & Prohibitin-2 & 299 & 1.029 \\
\hline ALBU_HUMAN & P02768 & Serum albumin & 609 & 1.029 \\
\hline SPTN1_HUMAN & Q13813 & Spectrin $\alpha$ chain, non-erythrocytic 1 & 2,472 & 1.029 \\
\hline S10AE_HUMAN & Q9HCY8 & Protein S100-A14 & 104 & 1.029 \\
\hline HSPB1_HUMAN & P04792 & Heat shock protein $\beta-1$ & 205 & 1.029 \\
\hline PDIA3_HUMAN & P30101 & Protein disulfide-isomerase A3 & 505 & 1.071 \\
\hline 1433S_HUMAN & P31947 & $14-3-3$ protein $\sigma$ & 248 & 1.071 \\
\hline ACTG_HUMAN & P63261 & Actin, cytoplasmic 2 & 375 & 1.076 \\
\hline ACTBM_HUMAN & Q9BYX7 & Putative $\beta$-actin-like protein 3 & 375 & 1.165 \\
\hline RSSA_HUMAN & P08865 & 40S ribosomal protein $\mathrm{SA}$ & 295 & 1.165 \\
\hline IASPP_HUMAN & Q8WUF5 & RelA-associated inhibitor & 828 & 1.190 \\
\hline FUMH_HUMAN & P07954 & Fumarate hydratase, mitochondrial & 510 & 1.190 \\
\hline HMGB1_HUMAN & P09429 & High mobility group protein B1 & 215 & 1.190 \\
\hline COR1B_HUMAN & Q9BR76 & Coronin-1B & 489 & 1.190 \\
\hline COTL1_HUMAN & Q14019 & Coactosin-like protein & 142 & 1.190 \\
\hline LA_HUMAN & P05455 & Lupus La protein & 408 & 1.190 \\
\hline NCBP1_HUMAN & Q09161 & Nuclear cap-binding protein subunit 1 & 790 & 1.190 \\
\hline SQRD_HUMAN & Q9Y6N5 & Sulfide:Quinone oxidoreductase, mitochondrial & 450 & 1.190 \\
\hline TRAP1_HUMAN & Q12931 & Heat shock protein $75 \mathrm{kDa}$, mitochondrial & 704 & 1.190 \\
\hline EZRI_HUMAN & P15311 & Ezrin & 586 & 1.190 \\
\hline RL22_HUMAN & P35268 & $60 \mathrm{~S}$ ribosomal protein $\mathrm{L} 22$ & 128 & 1.190 \\
\hline
\end{tabular}


Table I. Continued.

\begin{tabular}{|c|c|c|c|c|}
\hline ID & $\begin{array}{l}\text { Accession } \\
\text { number }\end{array}$ & Definition & $\begin{array}{l}\text { Number of } \\
\text { amino acids }\end{array}$ & $\begin{array}{c}\text { Fold } \\
\text { change (Rsc) }\end{array}$ \\
\hline RS3_HUMAN & P23396 & $40 \mathrm{~S}$ ribosomal protein $\mathrm{S} 3$ & 243 & 1.190 \\
\hline ARF4_HUMAN & P18085 & ADP-ribosylation factor 4 & 180 & 1.190 \\
\hline COR1C_HUMAN & Q9ULV4 & Coronin-1C & 474 & 1.190 \\
\hline MARE1_HUMAN & Q15691 & $\begin{array}{l}\text { Microtubule-associated protein } \mathrm{RP} / \mathrm{EB} \\
\text { family member } 1\end{array}$ & 268 & 1.190 \\
\hline MYO1B_HUMAN & O43795 & Unconventional myosin-Ib & 1,136 & 1.190 \\
\hline FREM1_HUMAN & Q5H8C1 & FRAS1-related extracellular matrix protein 1 & 2,179 & 1.190 \\
\hline VPS35_HUMAN & Q96QK1 & Vacuolar protein sorting-associated protein 35 & 796 & 1.190 \\
\hline TBA1C_HUMAN & Q9BQE3 & Tubulin $\alpha-1 C$ chain & 449 & 1.242 \\
\hline PRDX6_HUMAN & P30041 & Peroxiredoxin-6 & 224 & 1.257 \\
\hline SERPH_HUMAN & P50454 & Serpin H1 & 418 & 1.257 \\
\hline AN32B_HUMAN & Q92688 & $\begin{array}{l}\text { Acidic leucine-rich nuclear phosphoprotein } \\
32 \text { family member B }\end{array}$ & 251 & 1.334 \\
\hline CX6B1_HUMAN & P14854 & Cytochrome c oxidase subunit 6B1 & 86 & 1.334 \\
\hline ROA1_HUMAN & P09651 & Heterogeneous nuclear ribonucleoprotein A1 & 372 & 1.334 \\
\hline COX5A_HUMAN & P20674 & Cytochrome c oxidase subunit $5 \mathrm{~A}$, mitochondrial & 150 & 1.417 \\
\hline PSME1_HUMAN & Q06323 & Proteasome activator complex subunit 1 & 249 & 1.417 \\
\hline 4F2_HUMAN & P08195 & 4F2 cell-surface antigen heavy chain & 630 & 1.417 \\
\hline K1C9_HUMAN & P35527 & Keratin, type I cytoskeletal 9 & 623 & 1.528 \\
\hline LEG7_HUMAN & P47929 & Galectin-7 & 136 & 1.721 \\
\hline EIF3M_HUMAN & Q7L2H7 & Eukaryotic translation initiation factor 3 subunit $\mathrm{M}$ & 374 & 1.721 \\
\hline HNRDL_HUMAN & O14979 & Heterogeneous nuclear ribonucleoprotein D-like & 420 & 1.721 \\
\hline TCPB_HUMAN & P78371 & T-complex protein 1 subunit $\beta$ & 535 & 1.721 \\
\hline CPNE3_HUMAN & O75131 & Copine-3 & 537 & 1.721 \\
\hline DEST_HUMAN & P60981 & Destrin & 165 & 1.721 \\
\hline TFR1_HUMAN & P02786 & Transferrin receptor protein 1 & 760 & 1.721 \\
\hline CNDP2_HUMAN & Q96KP4 & Cytosolic non-specific dipeptidase & 475 & 1.721 \\
\hline AHSA1_HUMAN & O95433 & Activator of $90 \mathrm{kDa}$ heat shock protein ATPase homolog 1 & 338 & 1.721 \\
\hline DDB1_HUMAN & Q16531 & DNA damage-binding protein 1 & 1,140 & 1.721 \\
\hline ICAL_HUMAN & P20810 & Calpastatin & 708 & 1.721 \\
\hline ASNA_HUMAN & $\mathrm{O} 43681$ & ATPase ASNA1 & 348 & 1.721 \\
\hline CISY_HUMAN & O75390 & Citrate synthase, mitochondrial & 466 & 1.721 \\
\hline CSK23_HUMAN & Q8NEV1 & Casein kinase II subunit $\alpha 3$ & 391 & 1.721 \\
\hline CNN2_HUMAN & Q99439 & Calponin-2 & 309 & 1.721 \\
\hline SYYC_HUMAN & P54577 & Tyrosine-tRNA ligase, cytoplasmic & 528 & 1.721 \\
\hline SODM_HUMAN & P04179 & Superoxide dismutase $[\mathrm{Mn}]$, mitochondrial & 222 & 1.721 \\
\hline ACTY_HUMAN & P42025 & B-centractin & 376 & 1.721 \\
\hline ML12A_HUMAN & P19105 & Myosin regulatory light chain $12 \mathrm{~A}$ & 171 & 1.721 \\
\hline RL32_HUMAN & P62910 & 60 S ribosomal protein L32 & 135 & 1.721 \\
\hline MYO1C_HUMAN & O00159 & Unconventional myosin-Ic & 1,063 & 1.721 \\
\hline FSCN1_HUMAN & Q16658 & Fascin & 493 & 1.722 \\
\hline RL3_HUMAN & P39023 & $60 \mathrm{~S}$ ribosomal protein L3 & 403 & 1.722 \\
\hline RPN1_HUMAN & P04843 & $\begin{array}{l}\text { Dolichyl-diphosphooligosaccharide-protein } \\
\text { glycosyltransferase subunit } 1\end{array}$ & 607 & 1.722 \\
\hline B2MG_HUMAN & P61769 & B-2-microglobulin & 119 & 1.722 \\
\hline RBP56_HUMAN & Q92804 & TATA-binding protein-associated factor $2 \mathrm{~N}$ & 592 & 1.722 \\
\hline 2AAA_HUMAN & P30153 & $\begin{array}{l}\text { Serine/threonine-protein phosphatase } 2 \mathrm{~A} 65 \mathrm{kDa} \\
\text { regulatory subunit } \mathrm{A} \alpha \text { isoform }\end{array}$ & 589 & 1.722 \\
\hline ENOG_HUMAN & P09104 & $\Gamma$-enolase & 434 & 1.722 \\
\hline RL27A_HUMAN & P46776 & $60 S$ ribosomal protein $\mathrm{L} 27 \mathrm{a}$ & 148 & 1.722 \\
\hline DCD_HUMAN & P81605 & Dermcidin & 110 & 1.722 \\
\hline
\end{tabular}


Table I. Continued.

\begin{tabular}{|c|c|c|c|c|}
\hline ID & $\begin{array}{c}\text { Accession } \\
\text { number }\end{array}$ & Definition & $\begin{array}{l}\text { Number of } \\
\text { amino acids }\end{array}$ & $\begin{array}{c}\text { Fold } \\
\text { change (Rsc) }\end{array}$ \\
\hline RS7_HUMAN & P62081 & 40S ribosomal protein $\mathrm{S} 7$ & 194 & 1.722 \\
\hline IQGA1_HUMAN & P46940 & Ras GTPase-activating-like protein IQGAP1 & 1,657 & 1.723 \\
\hline TERA_HUMAN & P55072 & Transitional endoplasmic reticulum ATPase & 806 & 1.723 \\
\hline SPTB2_HUMAN & Q01082 & Spectrin $\beta$ chain, non-erythrocytic 1 & 2,364 & 1.723 \\
\hline RL18A_HUMAN & Q02543 & $60 \mathrm{~S}$ ribosomal protein L18a & 176 & 1.723 \\
\hline CALX_HUMAN & P27824 & Calnexin & 592 & 1.723 \\
\hline TBA4B_HUMAN & Q9H853 & Putative tubulin-like protein $\alpha-4 B$ & 241 & 1.724 \\
\hline TCPE_HUMAN & P48643 & T-complex protein 1 subunit $\varepsilon$ & 541 & 1.724 \\
\hline K2C80_HUMAN & Q6KB66 & Keratin, type II cytoskeletal 80 & 452 & 1.724 \\
\hline HNRPK_HUMAN & P61978 & Heterogeneous nuclear ribonucleoprotein $\mathrm{K}$ & 463 & 1.865 \\
\hline VPP4_HUMAN & Q9HBG4 & V-type proton ATPase $116 \mathrm{kDa}$ subunit a isoform 4 & 840 & 2.029 \\
\hline EF1G_HUMAN & P26641 & Elongation factor $1-\gamma$ & 437 & 2.110 \\
\hline G6PI_HUMAN & P06744 & Glucose-6-phosphate isomerase & 558 & 2.110 \\
\hline H2B1M_HUMAN & Q99879 & Histone $\mathrm{H} 2 \mathrm{~B}$ type $1-\mathrm{M}$ & 126 & 2.119 \\
\hline RALY_HUMAN & Q9UKM9 & RNA-binding protein Raly & 306 & 2.253 \\
\hline TXTP_HUMAN & P53007 & Tricarboxylate transport protein, mitochondrial & 311 & 2.253 \\
\hline CAN1_HUMAN & P07384 & Calpain-1 catalytic subunit & 714 & 2.253 \\
\hline DHB12_HUMAN & Q53GQ0 & Estradiol $17-\beta$-dehydrogenase 12 & 312 & 2.253 \\
\hline DHX9_HUMAN & Q08211 & ATP-dependent RNA helicase A & 1,270 & 2.253 \\
\hline MYADM_HUMAN & Q96S97 & Myeloid-associated differentiation marker & 322 & 2.253 \\
\hline CUTA_HUMAN & O60888 & Protein CutA & 179 & 2.253 \\
\hline CECR2_HUMAN & Q9BXF3 & Cat eye syndrome critical region protein 2 & 1,484 & 2.253 \\
\hline KRT81_HUMAN & Q14533 & Keratin, type II cuticular Hb1 & 505 & 2.569 \\
\hline GLOD4_HUMAN & Q9HC38 & Glyoxalase domain-containing protein 4 & 313 & 2.569 \\
\hline SURF4_HUMAN & O15260 & Surfeit locus protein 4 & 269 & 2.569 \\
\hline P4HA1_HUMAN & P13674 & Prolyl 4-hydroxylase subunit $\alpha-1$ & 534 & 2.569 \\
\hline ANX11_HUMAN & P50995 & Annexin A11 & 505 & 2.569 \\
\hline CALU_HUMAN & $\mathrm{O} 43852$ & Calumenin & 315 & 2.569 \\
\hline TFG_HUMAN & Q92734 & Protein TFG & 400 & 2.569 \\
\hline ECHA_HUMAN & P40939 & Trifunctional enzyme subunit $\alpha$, mitochondrial & 763 & 2.569 \\
\hline PA2G4_HUMAN & Q9UQ80 & Proliferation-associated protein $2 \mathrm{G} 4$ & 394 & 2.569 \\
\hline SF3A2_HUMAN & Q15428 & Splicing factor $3 \mathrm{~A}$ subunit 2 & 464 & 2.569 \\
\hline SHLB2_HUMAN & Q9NR46 & Endophilin-B2 & 395 & 2.569 \\
\hline MBOA7_HUMAN & Q96N66 & Lysophospholipid acyltransferase 7 & 472 & 2.569 \\
\hline AT1A1_HUMAN & P05023 & Sodium/potassium-transporting ATPase subunit $\alpha-1$ & 1,023 & 2.569 \\
\hline PPME1_HUMAN & Q9Y570 & Protein phosphatase methylesterase 1 & 386 & 2.569 \\
\hline IF4G2_HUMAN & P78344 & Eukaryotic translation initiation factor $4 \gamma 2$ & 907 & 2.569 \\
\hline IPYR2_HUMAN & Q9H2U2 & Inorganic pyrophosphatase 2 , mitochondrial & 334 & 2.569 \\
\hline CKAP4_HUMAN & Q07065 & Cytoskeleton-associated protein 4 & 602 & 2.569 \\
\hline COPB2_HUMAN & P35606 & Coatomer subunit $\beta$ & 906 & 2.569 \\
\hline DLG1_HUMAN & Q12959 & Disks large homolog 1 & 904 & 2.569 \\
\hline ATX2L_HUMAN & Q8WWM7 & Ataxin-2-like protein & 1,075 & 2.569 \\
\hline RMXL1_HUMAN & Q96E39 & RNA binding motif protein, $\mathrm{X}$-linked-like-1 & 390 & 2.569 \\
\hline CERS2_HUMAN & Q96G23 & Ceramide synthase 2 & 380 & 2.569 \\
\hline RM46_HUMAN & Q9H2W6 & 39S ribosomal protein L46, mitochondrial & 279 & 2.569 \\
\hline FDFT_HUMAN & P37268 & Squalene synthase & 417 & 2.569 \\
\hline CP26A_HUMAN & O43174 & Cytochrome P450 26A1 & 497 & 2.569 \\
\hline EIF3A_HUMAN & Q14152 & Eukaryotic translation initiation factor 3 subunit A & 1,382 & 2.569 \\
\hline GLYM_HUMAN & P34897 & Serine hydroxymethyltransferase, mitochondrial & 504 & 2.569 \\
\hline ARHGJ_HUMAN & Q8IW93 & Rho guanine nucleotide exchange factor 19 & 802 & 2.569 \\
\hline
\end{tabular}


Table I. Continued.

\begin{tabular}{|c|c|c|c|c|}
\hline ID & $\begin{array}{l}\text { Accession } \\
\text { number }\end{array}$ & Definition & $\begin{array}{l}\text { Number of } \\
\text { amino acids }\end{array}$ & $\begin{array}{l}\text { Fold } \\
\text { change (Rsc) }\end{array}$ \\
\hline GFPT1_HUMAN & Q06210 & $\begin{array}{l}\text { Glutamine-fructose-6-phosphate aminotransferase } \\
\text { [isomerizing] } 1\end{array}$ & 699 & 2.569 \\
\hline NOD2_HUMAN & Q9HC29 & $\begin{array}{l}\text { Nucleotide-binding oligomerization } \\
\text { domain-containing protein } 2\end{array}$ & 1,040 & 2.569 \\
\hline NAGK_HUMAN & Q9UJ70 & $\mathrm{N}$-acetyl-D-glucosamine kinase & 344 & 2.569 \\
\hline SYAC_HUMAN & P49588 & Alanine-tRNA ligase, cytoplasmic & 968 & 2.569 \\
\hline CLAP1_HUMAN & Q7Z460 & CLIP-associating protein 1 & 1,538 & 2.569 \\
\hline SPTN4_HUMAN & Q9H254 & Spectrin $\beta$ chain, non-erythrocytic 4 & 2,564 & 2.569 \\
\hline MTU1_HUMAN & O75648 & Mitochondrial tRNA-specific 2-thiouridylase 1 & 421 & 2.569 \\
\hline PAOX_HUMAN & Q6QHF9 & $\begin{array}{l}\text { Peroxisomal N(1)-acetyl-spermine/spermidine } \\
\text { oxidase }\end{array}$ & 649 & 2.569 \\
\hline MCM5_HUMAN & P33992 & DNA replication licensing factor MCM5 & 734 & 2.569 \\
\hline WNK3_HUMAN & Q9BYP7 & Serine/threonine-protein kinase WNK3 & 1,800 & 2.569 \\
\hline LIMK2_HUMAN & P53671 & LIM domain kinase 2 & 638 & 2.569 \\
\hline VIPR2_HUMAN & P41587 & Vasoactive intestinal polypeptide receptor 2 & 438 & 2.569 \\
\hline DOS_HUMAN & Q8N350 & Protein Dos & 725 & 2.569 \\
\hline TRDN_HUMAN & Q13061 & Triadin $\mathrm{O}$ & 729 & 2.569 \\
\hline ZN318_HUMAN & Q5VUA4 & Zinc finger protein 318 & 2,279 & 2.569 \\
\hline SUCO_HUMAN & Q9UBS9 & SUN domain-containing ossification factor & 1,254 & 2.569 \\
\hline 2AAB_HUMAN & P30154 & $\begin{array}{l}\text { Serine/threonine-protein phosphatase } 2 \mathrm{~A} 65 \mathrm{kDa} \\
\text { regulatory subunit } \mathrm{A} \beta \text { isoform }\end{array}$ & 601 & 2.569 \\
\hline PCBP2_HUMAN & Q15366 & Poly $(\mathrm{rC})$-binding protein 2 & 365 & 2.569 \\
\hline 1433Z_HUMAN & P63104 & 14-3-3 protein $\zeta / \delta$ & 245 & 2.569 \\
\hline MDHC_HUMAN & P40925 & Malate dehydrogenase, cytoplasmic & 334 & 2.569 \\
\hline DNM1L_HUMAN & O00429 & Dynamin-1-like protein & 736 & 2.569 \\
\hline ARL8A_HUMAN & Q96BM9 & ADP-ribosylation factor-like protein $8 \mathrm{~A}$ & 186 & 2.569 \\
\hline DIAP1_HUMAN & O60610 & Protein diaphanous homolog 1 & 1,272 & 2.569 \\
\hline IF4H_HUMAN & Q15056 & Eukaryotic translation initiation factor $4 \mathrm{H}$ & 248 & 2.569 \\
\hline TEX35_HUMAN & Q5T0J7 & Testis-expressed sequence 35 protein & 233 & 2.569 \\
\hline GGCT_HUMAN & O75223 & $\Gamma$-glutamylcyclotransferase & 188 & 2.569 \\
\hline SF3A1_HUMAN & Q15459 & Splicing factor $3 \mathrm{~A}$ subunit 1 & 793 & 2.569 \\
\hline ARPC2_HUMAN & O15144 & Actin-related protein $2 / 3$ complex subunit 2 & 300 & 2.569 \\
\hline PP14B_HUMAN & Q96C90 & Protein phosphatase 1 regulatory subunit 14B & 147 & 2.569 \\
\hline ARHGH_HUMAN & Q96PE2 & Rho guanine nucleotide exchange factor 17 & 2,063 & 2.569 \\
\hline SYSC_HUMAN & P49591 & Serine-tRNA ligase, cytoplasmic & 514 & 2.569 \\
\hline ALPK2_HUMAN & Q86TB3 & A-protein kinase 2 & 2,170 & 2.569 \\
\hline SUSD3_HUMAN & Q96L08 & Sushi domain-containing protein 3 & 255 & 2.569 \\
\hline DP13B_HUMAN & Q8NEU8 & DCC-interacting protein $13-\beta$ & 664 & 2.569 \\
\hline XRCC6_HUMAN & P12956 & $\mathrm{X}$-ray repair cross-complementing protein 6 & 609 & 2.569 \\
\hline HBS1L_HUMAN & Q9Y450 & HBS1-like protein & 684 & 2.569 \\
\hline RK_HUMAN & Q15835 & Rhodopsin kinase & 563 & 2.569 \\
\hline SPRY7_HUMAN & Q5W111 & SPRY domain-containing protein 7 & 196 & 2.569 \\
\hline BRSK2_HUMAN & Q8IWQ3 & Serine/threonine-protein kinase BRSK2 & 736 & 2.569 \\
\hline STAT1_HUMAN & P42224 & Signal transducer and activator of transcription $1-\alpha / \beta$ & 750 & 2.569 \\
\hline ZEP1_HUMAN & P15822 & Zinc finger protein 40 & 2,718 & 2.569 \\
\hline SOX4_HUMAN & Q06945 & Transcription factor SOX-4 & 474 & 2.569 \\
\hline REXO1_HUMAN & Q8N1G1 & RNA exonuclease 1 homolog & 1,221 & 2.569 \\
\hline ZN521_HUMAN & Q96K83 & Zinc finger protein 521 & 1,311 & 2.569 \\
\hline DLG5_HUMAN & Q8TDM6 & Disks large homolog 5 & 1,919 & 2.569 \\
\hline TM155_HUMAN & Q4W5P6 & Protein TMEM155 & 130 & 2.569 \\
\hline ZYX_HUMAN & Q15942 & Zyxin & 572 & 2.569 \\
\hline
\end{tabular}


Table I. Continued.

\begin{tabular}{|c|c|c|c|c|}
\hline ID & $\begin{array}{l}\text { Accession } \\
\text { number }\end{array}$ & Definition & $\begin{array}{l}\text { Number of } \\
\text { amino acids }\end{array}$ & $\begin{array}{c}\text { Fold } \\
\text { change (Rsc) }\end{array}$ \\
\hline UBAC2_HUMAN & Q8NBM4 & Ubiquitin-associated domain-containing protein 2 & 344 & 2.569 \\
\hline STPG2_HUMAN & Q8N412 & Sperm-tail PG-rich repeat-containing protein 2 & 459 & 2.569 \\
\hline K0556_HUMAN & O60303 & Uncharacterized protein KIAA0556 & 1,618 & 2.569 \\
\hline KLH11_HUMAN & Q9NVR0 & Kelch-like protein 11 & 708 & 2.569 \\
\hline TTLL6_HUMAN & Q8N841 & Tubulin polyglutamylase TTLL6 & 843 & 2.569 \\
\hline CFA36_HUMAN & Q96G28 & Cilia- and flagella-associated protein 36 & 342 & 2.569 \\
\hline MMP14_HUMAN & P50281 & Matrix metalloproteinase-14 & 582 & 3.101 \\
\hline ADT1_HUMAN & P12235 & ADP/ATP translocase 1 & 298 & 3.101 \\
\hline GPNMB_HUMAN & Q14956 & Transmembrane glycoprotein NMB & 572 & 3.101 \\
\hline PYGL_HUMAN & P06737 & Glycogen phosphorylase, liver form & 847 & 3.101 \\
\hline NIPS2_HUMAN & O75323 & Protein NipSnap homolog 2 & 286 & 3.101 \\
\hline ERP29_HUMAN & P30040 & Endoplasmic reticulum resident protein 29 & 261 & 3.101 \\
\hline ADT3_HUMAN & P12236 & ADP/ATP translocase 3 & 298 & 3.101 \\
\hline LBN_HUMAN & Q86UK5 & Limbin & 1,308 & 3.101 \\
\hline RAB1B_HUMAN & Q9H0U4 & Ras-related protein Rab-1B & 201 & 3.201 \\
\hline TF_HUMAN & P13726 & Tissue factor & 295 & 3.490 \\
\hline
\end{tabular}

Rsc, $\log _{2}$ of the ratio of protein abundance; ATP, adenosine triphosphate; ADP, adenosine diphosphate; FRAS-1, fraser syndrome 1; MCM, minichromosome maintenance; WNK, with no K (lysine); DCC, deleted in colorectal cancer.

Table II. Differentially expressed proteins categorized as 'protein processing in endoplasmic reticulum' in a Gene Ontology analysis in human skin keratinocytes.

\begin{tabular}{|c|c|c|}
\hline Accession number & Description & Fold change (Rsc) \\
\hline P11142 & Heat shock cognate $71 \mathrm{kDa}$ protein & -1.577 \\
\hline P08238 & Heat shock protein HSP $90-\beta$ & -1.343 \\
\hline P30101 & Protein disulfide-isomerase A3 & 1.071 \\
\hline P04843 & Dolichyl-diphosphooligosaccharide-protein glycosyltransferase subunit 1 & 1.722 \\
\hline P27824 & Calnexin & 1.723 \\
\hline P55072 & Transitional endoplasmic reticulum ATPase & 1.723 \\
\hline P07384 & Calpain-1 catalytic subunit & 2.253 \\
\hline Q07065 & Cytoskeleton-associated protein 4 & 2.569 \\
\hline P30040 & Endoplasmic reticulum resident protein 29 & 3.101 \\
\hline
\end{tabular}

Rsc, $\log _{2}$ of the ratio of protein abundance.

expression is increased in $\mathrm{HaCaT}$ cells with $\mathrm{CP}$ treatment. Calpain-1 is a calcium-dependent intracellular cysteine protease $(47,48)$. It has an important role in various biological processes, including cell proliferation, cell migration, apoptosis and cytoskeletal remodeling $(49,50)$. Therefore, calpain is considered a therapeutic target for disorders involving inflammation, wound healing and tumor progression. A previous study reported that downregulation of calpain-1 expression in IgE-activated mast cells led to a reduced expression of cytokines, including IL- 6 and TNF- $\alpha$. Thus, they concluded that calpain-1 may regulate IgE-mediated allergic inflammation (51). Another study indicated that downregulation of calpain-1 expression in lung fibroblast cells also reduced the expression of cytokines, including IL-6, IL-8, and TNF- $\alpha$ (52). Furthermore, calpain-1 knockout mice exhibited impaired bactericidal activity in an acute bacterial peritonitis model, due to a reduction in IL-1 $\alpha$ production (53). Therefore, calpain-1 is considered a key factor in the immune response through its regulation of inflammation. Accordingly, it was hypothesized that $\mathrm{CP}$-induced increases in calpain-1 expression in $\mathrm{HaCaT}$ cells may affect the expression of inflammatory cytokines in keratinocytes. The present results support this hypothesis. Therefore, CP treatment may regulate the immune system in the setting of skin wounds.

In the present GO analysis in the category molecular function, several proteins classified as 'cadherin binding 

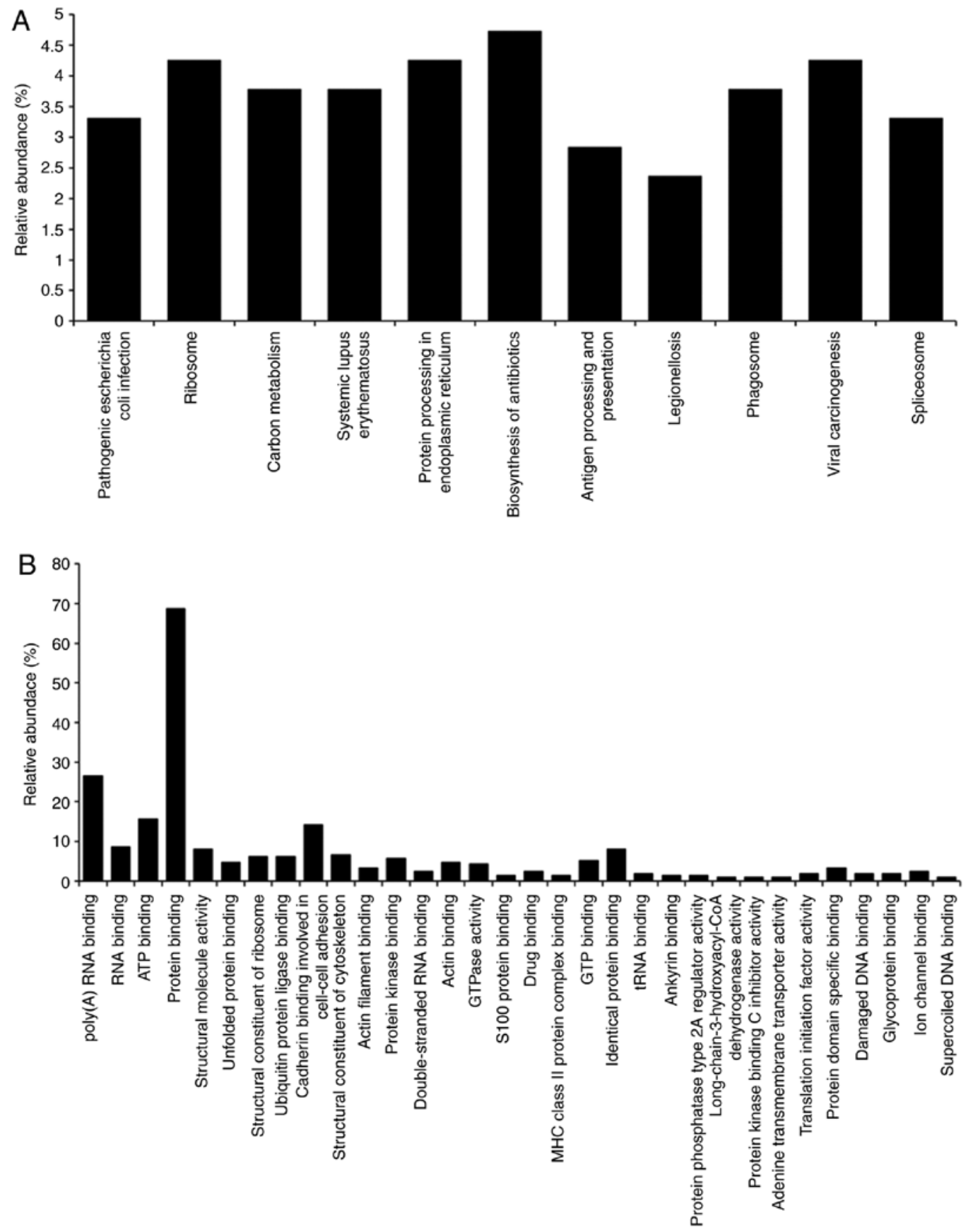

Figure 4. GO analysis of identified proteins. Differentially expressed proteins were assigned to KEGG signaling pathway and GO term categories. (A) KEGG signaling pathway terms. (B) GO molecular function terms. Only significant $(\mathrm{P}<0.05)$ categories are shown. KEGG, Kyoto Encyclopedia of Genes and Genomes; GO, Gene Ontology; MHC, major histocompatibility complex.

involved in cell-cell adhesion' exhibited altered expression with CP treatment. A previous study by our group reported that in $\mathrm{HaCaT}$ cells, these proteins were changed by treatment with collagen derived from soft-shelled turtle. Furthermore, it was observed that changing the expression of these proteins enhanced the wound healing properties of $\mathrm{HaCaT}$ cells by inducing EMT (34). In the present study, it was revealed that $\mathrm{CP}$ treatment was associated with $>2$-fold increases in ceramide synthase 2 expression in HaCaT cells compared with that in control cells (Table I). Ceramide is an epidermal sphingolipid that has important roles in maintaining the skin barrier and supporting wound healing processes (54-56). The present result is similar to previous ones reported for collagen derived from soft-shelled turtles and for CPs derived from other origins $(25,31,32,57)$. It is therefore suggested that CPs from soft-shelled turtles may facilitate wound healing.

Although the present study suggested that CPs from soft-shelled turtles may be a useful material for pharmaceuticals and medical products, it remains elusive whether these CPs affect the wound healing processes in keratinocytes in vivo. Of note, certain CP-regulated inflammatory cytokines including IL-6 and IL- 8 were not been investigated to determine their potential effects on the wound healing process in keratinocytes. Further in vitro and in vivo studies are necessary to clarify the effect of CPs from soft-shelled turtle on wound healing and the role of CP-regulated inflammatory 

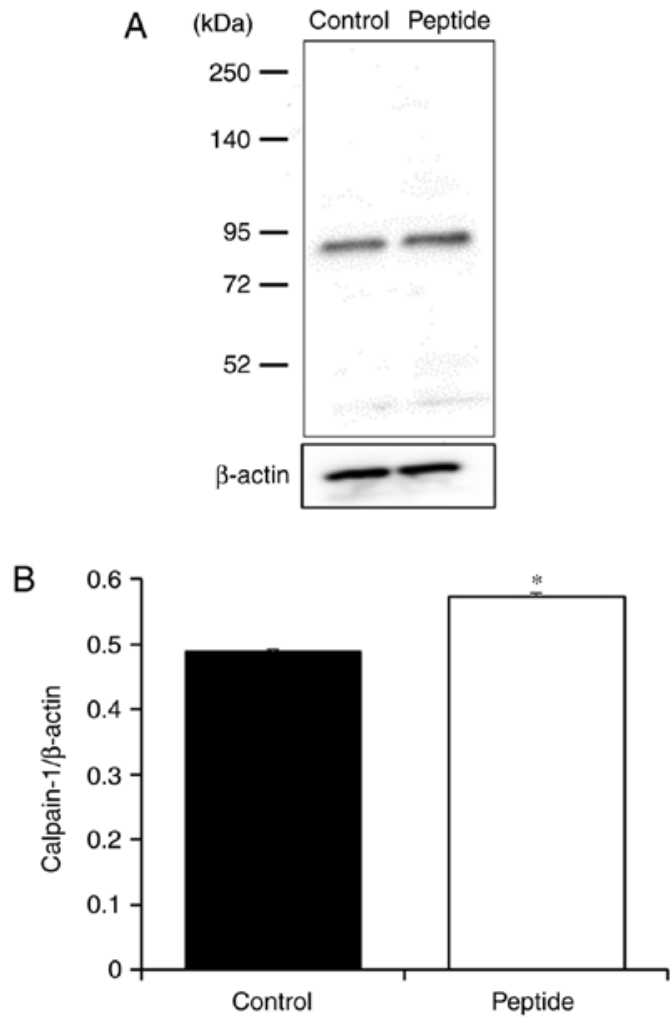

Figure 5. Expression of calpain-1 in collagen-peptide-treated $\mathrm{HaCaT}$ cells. (A) Western blot analysis indicates the expression levels of calpain-1 protein in $\mathrm{HaCaT}$ cells treated without (control) or with collagen peptides. (B) Quantification of western blot results. " $\mathrm{P}<0.05$ vs. control.
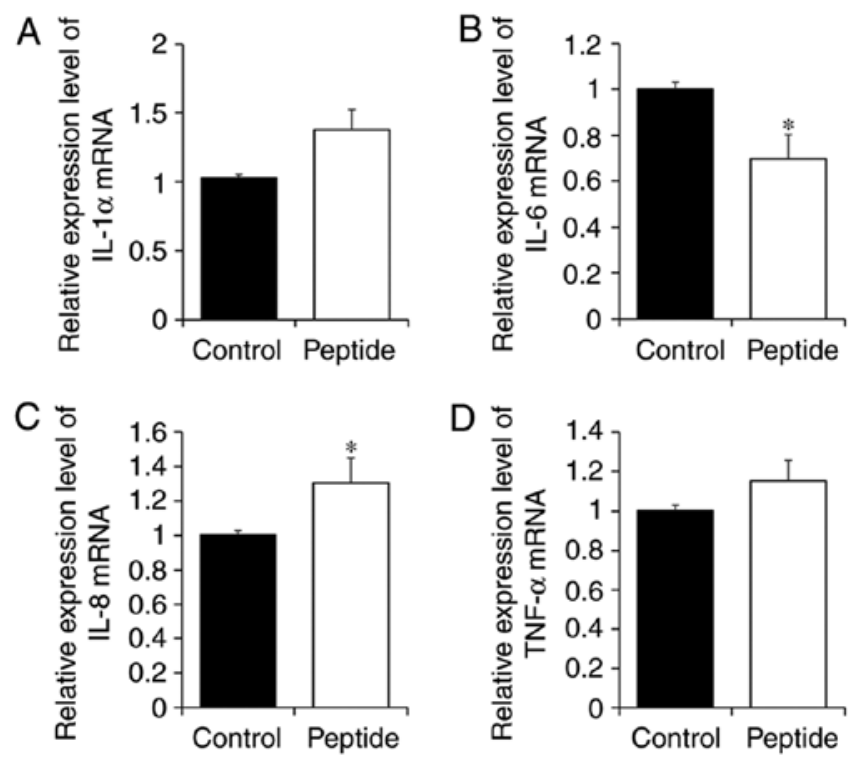

Figure 6. Cytokine expression changes in collagen-peptide treated HaCaT cells. Untreated cells (control) and collagen-peptide-treated HaCaT cells were analyzed by reverse-transcription quantitative polymerase chain reaction analysis. The collagen peptide-induced fold changes in the relative expression of inflammatory factors (A) IL-1 $\alpha$, (B) IL-6, (C) IL-8 and (D) TNF- $\alpha$ are indicated. The expression levels in the control group were set to 1 , and the fold changes after collagen peptide treatment were evaluated using the $2^{-\Delta \Delta \mathrm{Cq}}$ method. ${ }^{*} \mathrm{P}<0.05$ vs. control. IL, interleukin; TNF, tumor necrosis factor.

cytokines in keratinocytes. In addition, it is also necessary to investigate the correlation between the expression of calpain-1 and inflammatory cytokines in CP-treated keratinocytes.

In conclusion, the present shotgun LC/MS-based global proteomic analysis revealed that $\mathrm{CP}$ treatment regulated the expression of inflammatory cytokines in $\mathrm{HaCaT}$ cells and induced the expression of proteins associated with cell-cell adhesion and skin barrier maintenance. Therefore, CPs from soft-shelled turtles may provide significant benefits in maintaining the biological environment of the skin. These peptides may be a useful material for pharmaceuticals and medical products.

\section{Acknowledgements}

The authors are grateful to Mr. Takashi Aboshi (Shin-uoei, Inc.) for providing the soft-shelled turtle tissue used in the present study.

\section{Funding}

This study was supported in part by a Grant-in-Aid for Scientific Research (C) from the Japanese Society for the Promotion of Science to T.Y. (grant no. 15K09054).

\section{Availability of data and materials}

All data generated or analyzed during this study are included in this published article.

\section{Authors' contributions}

TY and AT designed the study and analyzed the data. TY and SN performed the experimental work. TY drafted the manuscript. KM contributed conduct the literature review. AT critically evaluated the study and final version of the manuscript. All authors participated in discussion of the study and gave final approval.

\section{Ethical approval and consent to participate}

Not applicable.

\section{Consent for publication}

Not applicable.

\section{Competing interests}

The authors declare that they have no competing interests.

\section{References}

1. Gelse K, Pöschl E and Aigner T: Collagens-structure, function, and biosynthesis. Adv Drug Deliv Rev 55: 1531-1546, 2003.

2. Myllyharju J and Kivirikko KI: Collagens, modifying enzymes and their mutations in humans, flies and worms. Trends Genet 20: 33-43, 2004.

3. Birk DE and Trelstad RL: Extracellular compartments in tendon morphogenesis: Collagen fibril, bundle, and macroaggregate formation. J Cell Biol 103: 231-240, 1986.

4. Adachi E and Hayashi T: Anchoring of epithelia to underlying connective tissue: Evidence of frayed ends of collagen fibrils directly merging with meshwork of lamina densa. J Electron Microsc (Tokyo) 43: 264-271, 1994. 
5. Park $\mathrm{KH}$ and Bae YH: Phenotype of hepatocyte spheroids in Arg-GLY-Asp (RGD) containing a thermo-reversible extracellular matrix. Biosci Biotechnol Biochem 66: 1473-1478, 2002.

6. Liu B, Weinzimer SA, Gibson TB, Mascarenhas D and Cohen P Type Ialpha collagen is an IGFBP-3 binding protein. Growth Hormone IGF Res 13: 89-97, 2003.

7. Di Lullo GA, Sweeney SM, Korkko J, Ala-Kokko L and San Antonio JD: Mapping the ligand-binding sites and disease-associated mutations on the most abundant protein in the human, type I collagen. J Biol Chem 277: 4223-4231, 2002.

8. Saby C, Buache E, Brassart-Pasco S, El Btaouri H, Courageot MP, Van Gulick L, Garnotel R, Jeannesson P and Morjani H: Type I collagen aging impairs discoidin domain receptor 2-mediated tumor cell growth suppression. Oncotarget 7: 24908-24927, 2016.

9. Maquoi E, Assent D, Detilleux J, Pequeux C, Foidart JM and Noël A: MT1-MMP protects breast carcinoma cells against type I collagen-induced apoptosis. Oncogene 31: 480-493, 2012.

10. Muralidharan N, Jeya Shakila R, Sukumar D and Jeyasekaran G: Skin, bone and muscle collagen extraction from the trash fish leather jacket (Odonus niger) and their characterization. J Food Sci Technol 50: 1106-1113, 2013.

11. Wang Y and Regenstein JM: Effect of EDTA, HCl, and citric acid on Ca salt removal from Asian (silver) carp scales prior to gelatin extraction. J Food Sci 74: C426-C431, 2009.

12. Wang C, Zhan CL, Cai QF, Du CH, Liu GM, Su WJ and Cao MJ: Expression and characterization of common carp (Cyprinus carpio) matrix metalloproteinase- 2 and its activity against type $\mathrm{I}$ collagen. J Biotechnol 177: 45-52, 2014.

13. Benjakul S, Thiansilakul Y, Visessanguan W, Roytrakul S, Kishimura H, Prodpran T and Meesane J: Extraction and characterisation of pepsin-solubilised collagens from the skin of bigeye snapper (Priacanthus tayenus and Priacanthus macracanthus) J Sci Food Agric 90: 132-138, 2010.

14. Nalinanon S, Benjakul S and Kishimura H: Collagens from the skin of arabesque greenling (Pleurogrammus azonus) solubilized with the aid of acetic acid and pepsin from albacore tuna (Thunnus alalunga) stomach. J Sci Food Agric 90: 1492-1500, 2010.

15. Tziveleka LA, Ioannou E, Tsiourvas D, Berillis P, Foufa E and Roussis V: Collagen from the marine sponges Axinella cannabina and Suberites carnosus: Isolation and morphological, biochemical, and biophysical characterization. Mar Drugs 15: E152, 2017.

16. Pallela R, Venkatesan J, Janapala VR and Kim SK: Biophysicochemical evaluation of chitosan-hydroxyapatite-marine sponge collagen composite for bone tissue engineering. J Biomed Mater Res A 100: 486-495, 2012.

17. Coelho RCG, Marques ALP, Oliveira SM, Diogo GS, Pirraco RP, Moreira-Silva J, Xavier JC, Reis RL, Silva TH and Mano JF: Extraction and characterization of collagen from Antarctic and Sub-Antarctic squid and its potential application in hybrid scaffolds for tissue engineering. Mater Sci Eng C Mater Biol Appl 78 : 787-795, 2017.

18. Gorell ES, Leung TH, Khuu P and Lane AT: Purified type I collagen wound matrix improves chronic wound healing in patients with recessive dystrophic epidermolysis bullosa. Pediatr Dermat 32: 220-225, 2015.

19. Shevchenko RV, Sibbons PD, Sharpe JR and James SE: Use of a novel porcine collagen paste as a dermal substitute in full-thickness wounds. Wound Repair Regen 16: 198-207, 2008.

20. Wollina U, Meseg A and Weber A: Use of a collagen-elastin matrix for hard to treat soft tissue defects. Int Wound $\mathrm{J} 8$ : 291-296, 2011

21. Barhoumi A, Salvador-Culla B and Kohane DS: NIR-triggered drug delivery by collagen-mediated second harmonic generation. Adv Healthc Mater 4: 1159-1163, 2015.

22. Wallace DG and Rosenblatt J: Collagen gel systems for sustained delivery and tissue engineering. Adv Drug Deliv Rev 55: 1631-1649, 2003.

23. Friess W: Collagen-biomaterial for drug delivery. Eur J Pharm Biopharm 45: 113-136, 1998.

24. Song H, Zhang S, Zhang L and Li B: Effect of orally administered collagen peptides from bovine bone on skin aging in chronologically aged mice. Nutrients 9: E1209, 2017.

25. Hu Z, Yang P, Zhou C, Li S and Hong P: Marine collagen peptides from the skin of Nile Tilapia (Oreochromis niloticus): Characterization and wound healing evaluation. Mar Drugs 15: E102, 2017.

26. Zhuang Y, Hou H, Zhao X, Zhang Z and Li B: Effects of collagen and collagen hydrolysate from jellyfish (Rhopilema esculentum) on mice skin photoaging induced by UV irradiation. J Food Sci 74: H183-H188, 2009.
27. Zague V: A new view concerning the effects of collagen hydrolysate intake on skin properties. Arch Dermatol Res 300: 479-483, 2008.

28. Fan J, Zhuang Y and Li B: Effects of collagen and collagen hydrolysate from jellyfish umbrella on histological and immunity changes of mice photoaging. Nutrients 5: 223-233, 2013.

29. Hou H, Li B, Zhang Z, Xue C, Yu G, Wang J, Bao Y, Bu L, Sun J, Peng $\mathrm{Z}$ and Su S: Moisture absorption and retention properties, and activity in alleviating skin photodamage of collagen polypeptide from marine fish skin. Food Chem 135: 1432-1439, 2012

30. Song H, Meng M, Cheng X, Li B and Wang C: The effect of collagen hydrolysates from silver carp (Hypophthalmichthys molitrix) skin on UV-induced photoaging in mice: Molecular weight affects skin repair. Food Funct 8: 1538-1546, 2017.

31. Zhang Z, Wang J, Ding Y, Dai X and Li Y: Oral administration of marine collagen peptides from Chum Salmon skin enhances cutaneous wound healing and angiogenesis in rats. J Sci Food Agric 91: 2173-2179, 2011

32. Wang J, Xu M, Liang R, Zhao M, Zhang Z and Li Y: Oral administration of marine collagen peptides prepared from chum salmon (Oncorhynchus keta) improves wound healing following cesarean section in rats. Food Nutr Res 59: 26411, 2015.

33. Yamamoto T, Uemura K, Sawashi Y, Mitamura K and Taga A: Optimization of method to extract collagen from 'Emperor' tissue of soft-shelled turtles. J Oleo Sci 65: 169-175, 2016

34. Yamamoto T, Nakanishi S, Mitamura K and Taga A: Shotgun label-free proteomic analysis for identification of proteins in $\mathrm{HaCaT}$ human skin keratinocytes regulated by the administration of collagen from soft-shelled turtle. J Biomed Mater Res B Appl Biomater, 2017.

35. Schägger H: Tricine-SDS-PAGE. Nat Protoc 1: 16-22, 2006.

36. Bluemlein $\mathrm{K}$ and Ralser $\mathrm{M}$ : Monitoring protein expression in whole-cell extracts by targeted label- and standard-free LC-MS/MS. Nat Protoc 6: 859-869, 2011.

37. Old WM, Meyer-Arendt K, Aveline-Wolf L, Pierce KG, Mendoza A, Sevinsky JR, Resing KA and Ahn NG: Comparison of label-free methods for quantifying human proteins by shotgun proteomics. Mol Cell Proteomics 4: 1487-1502, 2005.

38. Zybailov B, Coleman MK, Florens L and Washburn MP: Correlation of relative abundance ratios derived from peptide ion chromatograms and spectrum counting for quantitative proteomic analysis using stable isotope labeling. Anal Chem 77: 6218-6224, 2005.

39. Dennis G Jr, Sherman BT, Hosack DA, Yang J, Gao W, Lane HC and Lempicki RA: DAVID: Database for annotation, visualization, and integrated discovery. Genome Biol 4: P3, 2003.

40. Huang da W, Sherman BT and Lempicki RA: Systematic and integrative analysis of large gene lists using DAVID bioinformatics resources. Nat Protoc 4: 44-57, 2009.

41. Huang da W, Sherman BT and Lempicki RA: Bioinformatics enrichment tools: Paths toward the comprehensive functional analysis of large gene lists. Nucleic Acids Res 37: 1-13, 2009.

42. Parikh $\mathrm{P}$, Bai $\mathrm{H}$, Swartz MF, Alfieris GM and Dean DA: Identification of differentially regulated genes in human patent ductus arteriosus. Exp Biol Med (Maywood) 241: 2112-2118, 2016.

43. Livak KJ and Schmittgen TD: Analysis of relative gene expression data using real-time quantitative PCR and the 2(-Delta Delta $\mathrm{C}(\mathrm{T})$ ) method. Methods 25: 402-408, 2001.

44. Carbotti G, Nikpoor AR, Vacca P, Gangemi R, Giordano C, Campelli F, Ferrini S and Fabbi M: IL-27 mediates HLA class I up-regulation, which can be inhibited by the IL- 6 pathway, in HLA-deficient small cell lung cancer cells. J Exp Clin Cancer Res 36: 140, 2017.

45. Adnan M, Morton G and Hadi S: Analysis of rpoS and bolA gene expression under various stress-induced environments in planktonic and biofilm phase using $2(-\Delta \Delta \mathrm{CT})$ method. Mol Cell Biochem 357: 275-282, 2011.

46. Soejima M and Koda Y: TaqMan-based real-time polymerase chain reaction for detection of FUT2 copy number variations: Identification of novel Alu-mediated deletion. Transfusion 51: 762-769, 2011.

47. Goll DE, Thompson VF, Li H, Wei W and Cong J: The calpain system. Physiol Rev 83: 731-801, 2003.

48. Momeni HR: Role of calpain in apoptosis. Cell J 13: 65-72, 2011

49. Glading A, Lauffenburger DA and Wells A: Cutting to the chase: Calpain proteases in cell motility. Trends Cell Biol 12: 46-54, 2002.

50. Sorimachi H, Ishiura S and Suzuki K: Structure and physiological function of calpains. Biochem J 328: 721-732, 1997. 
51. Wu Z, Chen X, Liu F, Chen W, Wu P, Wieschhaus AJ, Chishti AH, Roche PA, Chen WM and Lin TJ: Calpain-1 contributes to IgE-mediated mast cell activation. J Immunol 192: 5130-5139, 2014.

52. Yin G, Zeng Q, Zhao H, Wu P, Cai S, Deng L and Jiang W: Effect and mechanism of calpains on pediatric lobar pneumonia Bioengineered 8: 374-382, 2017.

53. Kumar V, Everingham S, Hall C, Greer PA and Craig AW: Calpains promote neutrophil recruitment and bacterial clearance in an acute bacterial peritonitis model. Eur J Immunol 44: 831-841, 2014

54. Kim H, Kim J, Park J, Kim SH, Uchida Y, Holleran WM and Cho Y: Water extract of gromwell (Lithospermum erythrorhizon) enhances migration of human keratinocytes and dermal fibroblasts with increased lipid synthesis in an in vitro wound scratch model. Skin Pharmacol Physiol 25: 57-64, 2012.
55. Amen N, Mathow D, Rabionet M, Sandhoff R, Langbein L, Gretz N, Jäckel C, Gröne HJ and Jennemann R: Differentiation of epidermal keratinocytes is dependent on glucosylceramide: Ceramide processing. Hum Mol Genet 22: 4164-4179, 2013.

56. Meckfessel MH and Brandt S: The structure, function, and importance of ceramides in skin and their use as therapeutic agents in skin-care products. J Am Acad Dermatol 71: 177-184, 2014.

57. Gangwar M, Gautam MK, Ghildiyal S, Nath G and Goel RK: Mallotus philippinensis Muell. Arg fruit glandular hairs extract promotes wound healing on different wound model in rats. BMC Complement Altern Med 15: 123, 2015. 